\title{
ECONOMY, AGRICULTURE AND THE ENVIRONMENT IN THE SELECTED PARTS OF THE WORLD
}

\author{
ARKADIUSZ SADOWSKI
}

\begin{abstract}
The aim of the study is to identify the different impacts of the economy and agriculture on the environment in the different countries in natural, historical, political and economic terms. Two countries were chosen as an examplethe USA and China, and one group of countries - the European Union. The research used data from Faostat and the World Bank. It also used the author's method of estimation of agricultural production, defined as the amount of energy expressed in kilocalories. Research showed that highly developed economies are highly polutogenic, but, on the other hand, they are effective, which means that the production of GDP entails relatively little pollution. In the case of agriculture, it was stated that productivity is determined primarily by demographic factors, mainly the density of population. It means that despite the differences in the level of development, the productivity of land is relatively high in China and the EU and lower in the USA. Basing on the analyses, a number of development dilemmas were pointed out, highlighting the social importance of multi-faceted security generated by the developed economy. At the same time, environmental threats were also identified.
\end{abstract}

Keywords: global agriculture, impact of agriculture on the environment, greenhouse gases, United States of America, European Union.

JEL codes: Q01, Q18, Q51, Q54.

Dr hab. Arkadiusz Sadowski, Uniwersytet Przyrodniczy w Poznaniu, Wydział Ekonomiczno-Społeczny, Katedra Ekonomii i Polityki Gospodarczej w Agrobiznesie, ul. Wojska Polskiego 28, 60-637 Poznań (arkadiusz.sadowski@up.poznan.pl). 


\section{Introduction}

For obvious reasons, food is one of the basic human needs, and ensuring an adequate supply of food is a concern for both farms and states. The vast majority of food around the world and throughout individual countries is made up of processed and unprocessed agricultural products. Agricultural production has a specific nature in many aspects. It has many more characteristic features, but this study focuses on the three fundamental issues.

First, it is an activity carried out in the natural environment, which means that it both modifies and depends on it (Sadowski, 2012). These are truths known from the inception of agriculture, which developed primarily in favourable natural conditions and, at the same time, led to significant transformation of the landscape, thus creating specific agroecosystems. Nowadays, these dependencies can also be observed in the form of climate change. Agricultural activity involves greenhouse gas emissions, so it contributes to the escalation of such change (Faber et al. 2012; Marcinkowski, 2010; Zieliński, 2016). These, in turn, affect production volume and specialisation, and in particular the possible location of specific crops, crop yield and stability (Grzelak and Stępień, 2011; Sachs, 2009).

The second important issue is the dependence of agriculture on the level of economic development and economic policies. Scientific and technological progress, industrial development and the resultant demand for jobs outside agriculture allow for reduction in employment in agriculture, simultaneously, providing those who continue their on-farm activity with an adequate technical equipment. This was the direction of the development and the economy in the past, but it can currently be observed that mechanisation, automation or digitisation often limit the number of jobs outside agriculture, which results in various forms of exclusion of entire social groups. Nonetheless, the more developed the economy, the more efficient the agriculture, and the better food security (Pawlak, 2016; Tomczak, 2000). On the other hand, intensification of production entails increased impact on the environment, covering also transformation of the landscape, use of industrial means of production, and (which has been particularly important in recent decades) greenhouse gas emissions (Kośmicki, 2008; Zegar, 2012). It should be noted, however, that a well-developed economy usually means a well-functioning state with a number of political instruments and an administrative apparatus at its disposal, which potentially allows for mitigation of the adverse environmental impact of the economy.

Another specific feature of agriculture is the strong mutual dependence on demographics. Without joining the debate on the direction of causality, it should be observed that at the most general level, agricultural production volume should correspond to the number of people and their individual demand for food. Hunger and malnutrition show that it is not always so. The presented selected aspects of agriculture and the economy lead to a number of dilemmas, particularly in regard to the relationship with the environment, including the climate change. It can be assumed that economic development does not only increase the comfort of living 
but also multidimensional security, including food security understood as uninterrupted physical and economic availability of food for all members of the society (Paszkowski, 2015). This is an indubitable good, whose achievement, however, entails some social costs, e.g. related to the aforementioned environmental impact of the economy (including agriculture). Therefore, individual countries or groups of countries try to develop mechanisms aimed at solving this dilemma, which should be understood both as intentional action (e.g. relevant political instruments, new production techniques) and unintentional processes resulting from the logic of development. Possible remedial measures depend on the above-factors, such as the level and dynamics of economic development, demographics, political instruments, and technological solutions.

\section{Reasons for the selection of the research topic}

Having regard to the above, the aim of the study is to show the diverse environmental impact of the economy and its specific sector, which is agriculture, in countries that differ in their natural conditions, history, politics, and their economies. The complexity of the phenomenon has resulted in the choice of a strongly reductionist approach, where the environmental impact is measured by the volume of greenhouse gas emissions (in terms of the $\mathrm{CO}_{2}$ equivalent) from, respectively, the entire economy and the agriculture. This was motivated by the importance of the climate issue in the early 21 st century and (which is important from the perspective of an analyst) by the comparability and uniformity of the measure, which can be used as a kind of environmental 'cost' of or 'input' to the economic activity. Referring to the traditional understanding of economic rationality, two approaches can be adopted here: minimisation of the input (understood as greenhouse gas emissions) with the assumed production volume or maximisation of production with the assumed input level. Particularly in regard to agriculture, whose products are necessary to live, the former approach seems the only socially and ethically acceptable one.

The analysis is based on two countries (the USA and China) and a group of countries - the European Union ${ }^{1}$. Such an approach resulted from the need to examine different relationships between the economy and agriculture and the environment depending on a number of characteristics of the civilisation (i.e. political, economic, and to some extent - historical) and the natural environment. Furthermore, the studied entities are very important on the global scale. Though, in total they take less than $19 \%$ of the Earth's land area, they are inhabited by nearly $34 \%$ of the global population, produce over $63 \%$ of the global GDP and are responsible for nearly a half of the greenhouse gas emissions (Table 1). As regards agriculture, they have about $24 \%$ of the global utilised agricultural area (UAA) at their disposal, where they produce over $38 \%$ of energy from agriculture and from where they emit over $31 \%$ of greenhouse gases from agriculture. The method for estimating the basic parameters (energy and emissions) will be presented in the section on

\footnotetext{
${ }^{1}$ In this study, the post-2007 European Union is examined as a whole due to the absence of barriers to market trade and uniform regulations under the Common Agricultural Policy.
} 
methodology.

Nonetheless, the analysed entities are characterised by a number of common and specific traits, which to a smaller or greater extent determine the current state of the studied phenomena. The countries that currently form the European Union and (in particular) China have a long tradition of statehood and, in turn, of developing science, literature, or philosophy. The combination of historical events and different approaches to progress, however, led to the situation where modernisation started in the $18^{\text {th }}$ century Europe and not elsewhere, soon joined by the United States that despite its short history has managed to form the world's largest economy. As a result, the wealth is the greatest in Europe and North America. China is currently trying to narrow the gap between them and the wealthiest part of the globe, hence decisions characteristic of an emerging economy rather than a developed one. This also pertains to the relationship between the economy and the environment, which is the topic of the below analyses.

Another characteristic shared by the EU countries and China is high population density, which to a large extent determines productivity of agriculture and the environmental cost. The agricultural sector in these two parts of the world, however, is significantly different, which will be shown in the results section. At this point, it is worth pointing to the fact that the European Union, as an area that, on the one hand, is characterised by large needs related to agriculture and, on the other, significant production capacity, has developed a specific form of regulating the sector, namely the Common Agricultural Policy, which currently (in the situation of a high level of food security) puts a strong emphasis on environmental issues. Similarly, the EU carries out a uniform climate policy, basically consisting in the EU regulations in the field of monitoring and measures aimed at emissions reduction. The situation in the United States is different, as population density is significantly lower, and thus the demographic pressure relatively small, while technological production capacity is far superior. Apart from this, China and the USA are characterised by natural and geographic conditions different from Europe. Both countries are situated on large continents that include regions both favourable and unfavourable for the development of agriculture. In Europe, due to its specific location in relation to the seas and the Atlantic Ocean and due to the predominance of fertile soils in the European lowlands, the conditions for agricultural development are favourable in most locations.

\section{Material and method}

The study uses data from the Faostat (www.faostat.fao.org) and from the World Bank (www.worldbank.org). As the newest available data refer to different years, the study was carried out using the averages for the 2000-2010 decade.

One of the most important variables used in the research is the energy from agriculture, which is not published in global databases, and was, therefore, estimated using the following algorithm: 


$$
\sum \mathrm{Ew}=\sum_{i=1}^{n} E s_{i} * P * W_{i}
$$

where:

$E w$ - amount of energy produced in agriculture (kcal/country),

$E s_{i}$ - energy consumption of the ith agricultural product (kcal/person/year),

$P$ - population (people/country),

$W_{i}$ - self-sufficiency coefficient for the ith product,

$$
\mathrm{W}_{\mathrm{i}}=\frac{P_{i}}{Z_{i}}
$$

where:

$P_{i} \quad-$ production of the ith product (t/country),

$Z_{i}$ - domestic consumprion of the ith product ( $\mathrm{t} /$ country).

The analysis uses Faostat data on the following products: meat, milk, offal, eggs, cereals, tuber and root crops, legumes, oilseed crops, vegetable fats, sugar crops and sugar, fruit, vegetables, spices, nuts, alcohol products.

This method was used to define a synthetic, physical unit of agricultural production volume (which, at the same time, includes both plant and animal production) not affected by inflation and exchange rates, which also refers to the essence of agricultural production, which is providing human organisms with energy.

The second fundamental variable used in the study is the volume of greenhouse gas emissions from the economy as a whole, and from agriculture. It is based on Faostat data. Unlike energy from agriculture (where there was a need to estimate it), the data was taken directly from the database. The study uses total emissions for all gases (i.e. $\mathrm{CO}_{2}, \mathrm{NO}_{\mathrm{x}}, \mathrm{CH}_{4}$, etc.) converted to the $\mathrm{CO}_{2}$ equivalent. Due to the nature of the study, whose aim is to show general links between the economy and agriculture and the environmental impact, no detailed issues related e.g. to the manner of land utilisation or specific production techniques in agriculture and other sectors were taken into consideration.

As regards the greenhouse gases, the following elements were taken into account in accordance with the approach used by Faostat: agriculture, energy, industry, land use, housing, transport, and losses.

Greenhouse gas emissions from agriculture, in turn, include (according to the Faostat nomenclature): enteric fermentation, manure management, rice cultivation, synthetic fertilisers, manure applied to soils, manure left on pasture, crop residues, burning of savanna, energy use.

Emissions from employment, however, were not included. Although labour intensity differs in individual countries, so the volumes of emissions due to employment are not equal, it was assumed that in the case of an alternative activity (in the industry or services sector), the volume of greenhouse gases emitted by the identical population would be similar. 
Individual analyses follow the convention that specific variables characterising the economy as a whole are expressed per a hectare of a country area, while variables related to the agriculture are expressed per hectare of utilised agricultural area.

\section{Results}

As shown in the introduction, the studied parts of the world are globally important, both in terms of wealth creation, food production, and environmental costs. It can be assumed that the economy as a whole and agriculture in particular largely serve the purpose of producing goods and services for inhabitants of the particular country or group of countries.

Therefore, it is important to determine the ratio of the percentage of the global population inhabiting the specific country or country group to the percentage resulting from the other analysed variables. The analysis whose results are shown in Table 1 aimed at evaluating the significance of the studied countries and country groups by indicating what percentage of global totals for population, GDP, total greenhouse gas emissions and emissions from agriculture, utilised agricultural area, and energy from agriculture these countries account for.

First, there is a need to notice that the EU and the USA are characterised by much higher participation in the generation of the global GDP compared to the percentage of the global population, which indicates a high level of economic development. This translates into emission volumes, which means that creation of wealth does not take place without environmental impact. The situation of China is different - the percentage of the global population is greater than the percentage of the GDP and the volume of emissions. The complete evaluation of this state of affairs is equivocal and far beyond the scope of this study, but there are still two aspects worth pointing to. On the one hand, wealthy countries generate wealth primarily from their populations, while the environmental cost is borne by the entire humanity, and populations of poor countries often bear the brunt of it. On the other hand, all progress generated in the wealthy countries is to a smaller or greater extent used worldwide, inter alia, developments in the field of medicine, transport, or telecommunications. Nonetheless, the differences between the wealthy and the poor are growing (Acemoglu and Robinson, 2014; Landes, 2017), and the number of related questions and dilemmas is not dwindling.

The case of the variables characterising agriculture and the related environmental costs is different, though. Above all, there is a need to notice that in this case each percentage is similar to the percentage of the global population, and the differences are much smaller than in the case of the entire economy. This particularly pertains to the amount of energy from agriculture and the volume of emissions. Firstly, this means that despite the difference in the economic importance of agriculture on the global scale, it plays a strategic role in ensuring food security everywhere. Secondly, this indicates that due to the security reasons, food supply comes primarily from domestic production.

Taking account of the greenhouse gas emissions from agriculture, it is clear that despite various agricultural systems (models) (Dubas, 2007; Kwasek and 
Obiedzińska, 2014; Krzyżanowski, Wrzaszcz and Zegar, 2015), differences in the countries' wealth, or arable land per capita, the percentage of greenhouse gas emissions from agricultural production is similar to the percentage of energy production everywhere. This, however, does not mean identical environmental cost (this issue will be discussed later on), but shows that regardless of the chosen path of agricultural development, production will always entail higher or lower emissions of greenhouse gasses (and other noxious substances). Of course, it should be borne in mind that methods reducing gas production are currently known and used (e.g. precision agriculture). It is also essential to mention that production techniques are different in the studied entities, which might be a consequence of the differences in the economic development level, percentage of workforce involved, or significant differences in the arable land per capita and, in turn, land use intensity.

Table 1

Importance of countries and groups (world $=100)$

\begin{tabular}{lcccccc}
\hline Specification & Population & $\begin{array}{c}\text { Gross } \\
\text { Domestic } \\
\text { Product }\end{array}$ & $\begin{array}{c}\text { Total } \\
\text { greenhouse gas } \\
\text { emissions }\end{array}$ & UAA & $\begin{array}{c}\text { Energy from } \\
\text { agriculture }\end{array}$ & $\begin{array}{c}\text { Greenhouse gas } \\
\text { emissions from } \\
\text { agriculture }\end{array}$ \\
\hline EU & 7.9 & 30.0 & 12.2 & 4.1 & 9.7 & 8.8 \\
USA & 4.8 & 27.2 & 16.3 & 8.7 & 7.1 & 7.4 \\
China & 21.1 & 6.4 & 18.1 & 11.0 & 21.7 & 15.0 \\
\hline
\end{tabular}

Source: own calculations based on data from www.faostat.fao.org and www.worldbank.org.

Table 2

Total wealth and total environmental costs of the economy

\begin{tabular}{lcccc}
\hline \multirow{2}{*}{ Specification } & \multirow{2}{*}{$\begin{array}{c}\text { GDP/capita } \\
\text { (USD) }\end{array}$} & \multicolumn{3}{c}{ Total greenhouse gas emissions } \\
\cline { 3 - 5 } & 29,116 & 11.6 & 13.2 & 0.4 \\
EU & 44,066 & 25.9 & 8.0 & 0.6 \\
USA & 2,340 & 6.5 & 8.9 & 2.8 \\
China & &
\end{tabular}

Source: own calculations based on data from www.faostat.fao.org and www.worldbank.org.

The environmental efficiency of the studied economies can be seen from various perspectives, which translates into different judgements in this regard. Above all, high level of economic development should be considered a generally desirable phenomenon from the social point of view, which is obvious from the perspective of the traditional economics, but nowadays frequently contested (Kośmicki, 2015). The main line of argument against achieving higher and higher development levels usually refers to the adverse environmental impact of the economy and production of goods and services that are actually unnecessary and demand for them is generated through aggressive marketing. 
Using the philosophical views of the stoics as a basis, Sedlácek (2015) reflects on the demand reduction as an alternative to permanently satisfying growing needs through increasing production (supply). Having regard to the reasonable nature of such opinions, there is a need to return to the earlier reflection on the fact that well-developed economies provide primarily multidimensional security. This includes health care, opportunities for employment and adequate pay or, finally, social security. This does not pertain equally to all the economically developed countries, where certain aspects directly related to security at a relatively low level, which is particularly visible in the form of poverty and social exclusion of significant portions of the population. Despite this, even the poorer portion of the affluent societies is at a smaller risk of hunger and malnutrition than major proportions of the population living in countries at a low development level.

It is also true that generation of wealth entails environmental impact. In the studied cases, the volume of emissions per capita (which can be referred to as the environmental cost of upkeep of an average resident at a relevant prosperity level) is proportional to the GDP per capita (Table 2). It should be noted, however, that the average income in the USA is higher than in the EU by about $50 \%$, while the emission volume per capita is over two times higher. Other correlations can be observed in relation to the amounts of greenhouse gas per 1 ha of country area. What is relevant here is the development level and population density, hence this parameter is the highest for the EU, while in the case of China and the USA, the values are similar despite the economic and political differences.

The study also attempts at a synthetic evaluation of the environmental cost intensity of the analysed economies with ratio of greenhouse gas emission volume to GDP as a measure. Creation of wealth results in less emissions per unit in the EU, while in China, it entails several times more emissions. The issue can be viewed from several perspectives. On the one hand, the results show that well-developed and stable economies are relatively not very cost intensive not only in the financial but also in the environmental terms. This can result from both microeconomic motivation of entrepreneurs (improvement in the economic efficiency of production through reduction in the use of means of production) and measures under an environmental policy. In this context, Kulawik (2016) notices that environmental regulations mobilise enterprises to implement technological innovations, which eventually translates into the improvement in their economic condition. China, being at the stage of 'catching up' with the most developed economies, aims primarily at achieving the maximum production output, which seems understandable from the social perspective. What is also important, is the fact that wealthy countries have the scientific and technological potential to develop solutions reducing the adverse environmental impact of the economy. On the other hand, however, it should be observed that although EU and the US economies are environmentally friendly per unit, they emit more greenhouse gases than their demographic potential would suggest. 
Table 3

Selected aspects of agriculture and food security

\begin{tabular}{lccccc}
\hline Specification & $\begin{array}{c}\text { Population } \\
\text { density } \\
\text { (people/km²) }\end{array}$ & $\begin{array}{c}\text { Arable land } \\
\text { per capita } \\
\text { (ha of UAA/ } \\
\text { person) }\end{array}$ & $\begin{array}{c}\text { Energy from } \\
\text { agriculture } \\
\text { (thousands kcal/ha } \\
\text { of UAA) }\end{array}$ & $\begin{array}{c}\text { Economically } \\
\text { active population } \\
\text { in agriculture } \\
\text { (economically active } \\
\text { population=100) }\end{array}$ & $\begin{array}{c}\text { Consumption } \\
\text { (kcal/person/ } \\
\text { day) }\end{array}$ \\
\hline EU & 113.4 & 0.39 & 3,054 & 5.3 & 3,401 \\
USA & 30.9 & 1.38 & 1,043 & 1.8 & 3,737 \\
China & 137.9 & 0.39 & 2,515 & 63.8 & 2,904 \\
\hline
\end{tabular}

Source: own calculations based on data from www.faostat.fao.org and www.worldbank.org.

As far as the subject of the analysis is concerned, the specific nature of agriculture is manifested by the fact that while it produces goods that satisfy the basic and irreducible needs, it is dependent on natural and demographic conditions, and on the level of economic development. These three factors largely determine its character in specific parts of the world. In the analysed case, specific countries and country groups are characterised by different population density, which translates into different arable land per capita (Table 3). This, in turn, forces productivity to be different, which is here examined in terms of kilocalories produced on each hectare of area used by agriculture. What is symptomatic is the strong similarity in land productivity between the EU and China, which also have similar population density and equal arable land per capita. The strategic importance of agriculture is clear here because the similarities are observed in entities that differ in wealth, or speaking more broadly, the stage of development, and also the political system. The agricultural models are also different - the dominant farm type in Europe, is the economically strong family farm with large capital at its disposal (Sadowski, Poczta, Szuba-Barańska and Beba, 2015), while in China the agrarian system is based on the state ownership of land rented by small producers (Li and Ren, 2014; Wieliczko, 2015). Similar demand, however, produced a similar effect.

The situation is different in the USA, where population density is relatively low, and the arable land per capita high. There, in spite of the country's wealth and the dominance of large farms with large capital (Tomczak, 2004), the production volume per unit is much lower than in China and the EU. Of course, it has to be emphasised that this is an average which is affected by less fertile soils in the American interior. Nevertheless, due to such a high arable land per capita, more extensive production is possible in the USA.

Differences in the agricultural models in specific studied cases can be indirectly observed through the percentage of active labour force employed in agriculture. Of course, wealthy countries, such as the USA and the EU Member States, have more opportunities to substitute labour with capital, which frees labour force from agriculture and enables other uses, thus driving the development spiral. In the case 
of China, this process is in progress. However, what is more important in the context of the studied issue, is the fact that agricultural productivity shows no correlation with the percentage of employed labour force (and the thus understood agricultural model), but it is the higher the smaller is the arable land per capita.

Other correlations can be observed in the case of the consumed calories per capita. What is important in this regard is the level of economic development. Skipping the issue of overconsumption, which is characteristic of highly developed countries, it is clear that consumption level is higher in the wealthy European Union and the United States than in China, which is just undergoing the process of industrialisation. This means that challenges faced by agriculture in specific countries and country groups result from the demographics, but the actual capability to remedy those problems is determined by the economy. This conclusion is particularly difficult in the context of the earlier observations on the significance of the economic development for ensuring multifaceted security, including food security. This is a commonly known fact, but it is worth recalling when speaking of the aforementioned relations between the economy and the environment.

Table 4

Environmental impact of agricultural production

\begin{tabular}{|c|c|c|c|}
\hline \multirow{2}{*}{ Specification } & \multicolumn{2}{|c|}{ Greenhouse gas emissions from agriculture } & \multirow{2}{*}{$\begin{array}{l}\text { Environmental cost of production } \\
\text { of energy from agriculture } \\
\left.\text { ( } \mathrm{kg} \text { of } \mathrm{CO}_{2} \text { eq. } / 1,000 \mathrm{kcal} \text { produced }\right)\end{array}$} \\
\hline & (t/ha of UAA) & (t/capita) & \\
\hline EU & 2.20 & 0.85 & 0.72 \\
\hline USA & 0.86 & 1.19 & 0.83 \\
\hline China & 1.38 & 0.54 & 0.55 \\
\hline
\end{tabular}

Source:o calculations based on data from www.faostat.fao.org and www.worldbank.org.

In the case of agriculture and the environment, the relations are different, and opinions about them also differ. The economy as such can be (largely justly) blamed for producing many unnecessary items in order to boost the market with artificially generated demand resulting from extensive promotion and advertising mechanisms. In a way, the case is similar for agriculture and the related agri-food industry. Waste of food or obesity epidemics not limited to wealthy countries, suggest that this sector also produces unnecessary items. In principle, however, agricultural production is necessary, and, as demonstrated above, it depends on demand due to demographic factors rather than the manner of production. Yet, it generates environmental costs as well (Table 4).

Emission volumes per 1 hectare of UAA is the highest where the production per unit is the largest, i.e. in China and the EU. Though, the measure used in this analysis, namely the volume of greenhouse gas emissions, does not satisfy the traditional definition of cost - it is not expressed using a monetary unit - the presented state of affairs complies with the fundamental logic of economics, where the cost is proportional to the scale of production. In the USA, due to the aforementioned lower land 
productivity, the greenhouse gas emissions per hectare of UAA are much lower. In the case of emissions per capita, there is an inverse relationship, which can be referred to as the environmental cost of nutrition. It is the highest in the USA and the lowest in China.

An important issue is to show the environmental cost intensity of agriculture expressed as the ratio of the greenhouse gas emissions to the production output. In this regard, the USA is the least efficient despite the fact that it is characterised by the most extensive production. The European Union and (in particular) China produce food intensively and all at once - efficiently. When assessing the environmental cost intensity of the entire economy, a number of comments and dilemmas have been presented, which are less relevant to agriculture or their dimension differs.

As evident, individual countries or groups of countries make effort to feed their population, which generates environmental cost - in this case, however, it is to a large degree reasonable and justified, excluding the said waste and overconsumption of food. Besides, the higher the demand and the extent to which it is satisfied, the lower the unit cost. In this case, the dilemma is different, and it is the best visible when examining the differences between China and the European Union. In China, the volume of greenhouse gases emitted due to production of $1,000 \mathrm{kcal}$ is much smaller than in the European Union. It is very likely than this results from lower capital intensity of Chinese agriculture, including less extensive use of industrial means of production. The relative (compared to the EU and the USA) low substitution of labour with capital can be seen through the aforementioned high percentage of labour force employed in agricultural production.

Therefore, the lower environmental cost also entails lower GDP with all the positive and negative consequences. Thus, the comments on the entire economy have returned with a new twist. It can be thought, however, that if economic development of China continues, the country will not cease (like the highly developed countries did in the past) to gradually substitute labour with capital, simultaneously, creating jobs outside agriculture. This will be done at the expense of the environment, but the unit environmental cost of the economy (understood as the amount of greenhouse gases per unit of GDP) will probably decrease. The society's need to grow rich will surely prevail, particularly due to the improvement in food security being an important aspect of this process.

\section{Conclusions}

Every country has a right, or rather a duty, to develop and provide its citizens with security, particularly in such a fundamental aspect as food security, but also environmental security. In the present, but seemingly also future, economic realities, however, this entails environmental pressure. This problem has a number of dimensions, but for the purpose of this study, reduced to the volume of greenhouse gas emissions, treated as a synthetic measure of environmental impact of the economy as a whole and of agriculture as its specific sector. The analyses carried out using selected examples show that the greater the production scale, the higher the environmental cost. 
This seems obvious, but its assessment from the perspective of social benefit and loss is not fully unambiguous. There is a need to balance the aforementioned multifaceted security, which is a 'by-product' of wealth, against the fact that environmental impact is an external cost, which should be seen both in spatial (effect on communities not directly participating in creation and distribution of the wealth) and temporal terms (impact on the future generations). In consequence, this means that ensuring food security is currently at the same time a hazard (at least potential, if no emission-reducing solutions are not developed) for the future.

An equally important conclusion from the study of the economy is the statement that larger production scale means smaller cost intensity per unit, which results from the greater opportunities for developing technological and organisational solutions in wealthy countries. It is apparent, however, that the impact on the global climate does not depend on the unit cost intensity of production but on the global volume of greenhouse gas emissions. Nonetheless, the improvement in efficiency gives hope that it is possible to reconcile the economic and social objectives (and thus the provision of adequate quality of life) with the environmental aims.

This pertains especially to agriculture, which provides products necessary to live. In this case, it is possible to dispute the proper production techniques or, in broader terms, agricultural models. The necessity to produce agricultural raw materials in quantities adequate to feed the entire population of the Earth is beyond dispute. This, however, entails and will entail environmental impact, including greenhouse gas emissions.

This study allows us to draw two seemingly contradictory conclusions. First of all (which makes results for agriculture and for the entire economy similar, higher productivity results in smaller environmental cost per unit. What is equally important, the demographic factor (population density and arable land per capita) is more important in this regard than the level of development, which by itself shows the specific nature of this sector. Therefore, the European and Chinese agriculture proved to be more environmentally friendly than the American agriculture despite significant differences in production techniques, agrarian structures, or agricultural policy.

The second conclusion, however, suggests the importance of the agricultural model, and China might serve as an example because in that country, production of every kilocalorie generates smaller emissions than in Europe, which has been attributed to the fact that the former has labour intensive agriculture, while the latter's model is capital intensive. Even though large percentage of labour force employed in food production is good for the environment, it is unfavourable for the society's wealth.

This study does not involve a historical approach, but the differences between the European Union, the USA and China can serve as an example of the development paths of the individual societies. Two centuries ago, the countries in the present EU (particularly the EU-15) initiated global economic change, nowadays referred to as the Industrial Revolution. They were soon joined by the United States, but the latter functioned in different conditions of the "New World", which is much more "empty" than the "Old World" even nowadays. 
All the historical, cultural and political differences aside, China is currently following a similar path, focusing primarily on intense industrialisation. If this process continues, it will inevitably lead to a growth in production and emissions (but also probably a drop in cost intensity per unit), and in relation to agriculture - substitution of labour with capital and a decrease in the percentage of the population employed in this sector. This is also likely to contribute to the increase in greenhouse gas emissions. It should not be presumed, however, that China or other developing countries will abandon the chosen path of growth because in the present conditions, it is the only one that provides an opportunity to improve the living conditions, to which these countries are equally entitled as the inhabitants of Europe and its so-called settlement colonies, i.e. mainly the USA, Canada and Australia, were in the past.

What seems to be the solution to this problem, where two equivalent goals are at odds, is to take measures aimed at decreasing the environmental cost intensity of the global economy rather than decreasing production, which neither businesses nor countries will agree to, and which will not be accepted by the society. This particularly pertains to agriculture, whose products are necessary to live, and, as demonstrated here, determined primarily by the demographic factor. To some extent, action aimed at improving environmental efficiency are (and will be) motivated by microeconomic premises and are related primarily to the principle of sound management, namely the achievement of the assumed goal with the minimum input possible. In this case, the private and the public interests converge, and possible solutions can be sought mainly among scientific achievements. Measures aimed at reduction in waste of food and harmful and unhealthy overconsumption should not be neglected as well. What is necessary here is action on the part of the state, mainly in the field of education. Another issue is provision of such solutions to poor countries, which is related to the complicated copyright matters. It seems, however, that it is necessary to take broader-ranging political measures, including application of standards, prohibitions and obligations, also in the area of international politics. The crux of the matter lies in the extent to which the developing countries will be able to implement specific instruments in practice in a situation where they do not have effective administrative apparatuses. 


\section{References}

Acemoglu, D., Robinson, J.A. (2014). Dlaczego narody przegrywaja. Poznań: Wydawnictwo Zysk i s-ka.

Dubas, A. (2007). Zrównoważony rozwój we współczesnych systemach rolnictwa. Fragmenta Agronomica, $\mathrm{nr}(3)$, pp. 71-75.

Faber, A., Borek, R., Borzęcka-Walker, M., Jarosz, Z., Kozyra, J., Pudełko, R., Syp, A., Zaliwski, A. (2012). Bilans węgla i emisji gazów cieplarnianych $\left(\mathrm{CO}_{2}, \mathrm{CH}_{4}\right.$ oraz $\left.\mathrm{NO}_{2}\right) \mathrm{w}$ polskim rolnictwie. In: J.S. Zegar (ed.), Z badań nad rolnictwem społecznie zrównoważonym (15) (pp. 9-37). Warszawa: IERiGŻ-PIB.

Grzelak, A., Stępień, S. (2011). Uwarunkowania i skutki zmian klimatycznych dla sektora rolnego - aspekty ekonomiczne. In: J.S. Zegar (ed.), Z badań nad rolnictwem społecznie zrównoważonym (11) (pp. 69-94). Warszawa: IERiGŻ-PIB.

Kośmicki, E. (2009). Podstawowe problemy ekologizacji polskiego rolnictwa. Próba eksplikacji głównych zagadnień. In: B. Fiedor, R. Jończy (ed.), Rozwój zrównoważony. Teoria i praktyka ze szczególnym uwzględnieniem obszarów wiejskich (pp. 121-138). Wrocław: Uniwersytet Ekonomiczny we Wrocławiu.

Kośmicki, E. (2015). Dokąd zmierza wspótczesna ekonomia, gospodarka i społeczeństwo. Podstawowe wyzwania koncepcji zrównoważonego rozwoju. Poznań-Białystok: Wydawnictwo Ekonomia i Środowisko.

Krzyżanowski, J., Wrzaszcz, W., Zegar, J.S. (2015). Z badań nad rolnictwem społecznie zrównoważonym (31). Warszawa: IERiGŻ-PIB.

Kulawik, J. (2016). Regulacje środowiskowe i innowacje a konkurencyjność. Zagadnienia Ekonomiki Rolnej, no. 1(346), pp. 3-21. DOI: 10.5604/00441600.1196358.

Kwasek, M., Obiedzińska, A. (2014). Zrównoważone systemy rolnicze zrównoważona dieta. Warszawa: IERiGŻ-PIB.

Landes, D.S. (2017). Bogactwo i nędza narodów. Dlaczego jedni są tak bogaci a inni tak ubodzy. Warszawa: Warszawskie Wydawnictwo Literackie Muza S.A.

Li, Z., Ren, C. (2014). Agriculture transition in China: experiences and lessons. Wieś i Rolnictwo, nr 3(164), pp. 25-44.

Marcinkowski, T. (2010). Emisja gazowych związków z rolnictwa. Woda-Środowisko-Obszary Wiejskie, t. 10, z. 3(31), pp. 175-189.

Paszkowski, S. (2015). Problemy światowego i europejskiego bezpieczeństwa żywnościowego. In: A. Czyżewski, B. Klepacki (ed.), Problemy rolnictwa i gospodarki żywnościowej w pierwszej dekadzie członkostwa Polski w Unii Europejskiej (pp. 363-384). Warszawa: Polskie Towarzystwo Ekonomiczne.

Pawlak, K. (2016). Food security situation of selected highly developed countries against developing countries. Journal of Agribussines and Rural Development, nr 2(40), pp. 385-398. DOI: 10.17306/JARD.2016.42.

Sachs, J. (2009). Nasze wspólne bogactwo. Ekonomia dla przeludnionej planety. Warszawa: Wydawnictwo Naukowe PWN.

Sadowski, A. (2012). Zrównoważony rozwój gospodarstw rolnych z uwzględnieniem wplywu Wspólnej Polityki Rolnej Unii Europejskiej. Poznań: Wydawnictwo Uniwersytetu Przyrodniczego w Poznaniu.

Sadowski, A., Poczta, W., Szuba-Barańska, E., Beba, P. (2015). Modele gospodarstw rolnych w państwach Unii Europejskiej. Wieś i rolnictwo, nr 3(168), pp. 43-62.

Sedláĉek, T. (2015). Ekonomia dobra i zła. W poszukiwaniu istoty ekonomii od Gilgamesza do Wall Street. Warszawa: Wydawnictwo Studio Emka. 
Tomczak, F. (2000). Rozwój rolnictwa światowego. Uwarunkowania i konsekwencje dochodowe. Warszawa: IERiGŻ-PIB.

Tomczak, F. (2004). Od rolnictwa do agrobiznesu. Transformacja gospodarki rolniczo-żywnościowej Stanów Zjednoczonych Ameryki Pótnocnej. Warszawa: Szkoła Głowna Handlowa.

Wieliczko, B. (2015). Polityka rolna Chin po 1978. Problemy Rolnictwa Światowego, t. 15, z. 1, pp. 144-153.

www.faostat.fao.org.

www.worldbank.org.

Zegar, J.S. (2012). Współczesne wyzwania rolnictwa. Warszawa: Wydawnictwo Naukowe PWN.

Zieliński, M. (2016). Emisja gazów cieplarnianych a wyniki ekonomiczne gospodarstw specjalizujacych się w uprawach polowych. Warszawa: IERiGŻ-PIB. 


\title{
GOSPODARKA, ROLNICTWO I ŚRODOWISKO W WYBRANYCH CZEŚSIACH ŚWIATA
}

\begin{abstract}
Abstrakt
Opracowanie ma na celu wskazanie zróżnicowanego oddziaływania na środowisko gospodarki, w tym rolnictwa, w państwach różniacych się pod względem uwarunkowań naturalnych, historycznych, politycznych i ekonomicznych. Jako przykład wybrano dwa kraje - USA i Chiny oraz jedno ugrupowanie państw - Unię Europejska. W badaniach wykorzystano dane pochodzace z zasobów Faostatu oraz Banku Światowego. Zastosowano autorska metodę szacowania wielkości produkcji rolniczej, określonej jako ilość energii wyrażonej $w$ kilokaloriach. W toku badań wykazano, że wysokorozwinięte gospodarki sa z jednej strony wysoce polutogenne, z drugiej zaś oszczędne, co oznacza, że wytworzenie jednostki PKB pociaga za soba generowanie relatywnie niewielkiej ilości zanieczyszczeń. W przypadku rolnictwa stwierdzono, że produktywność determinowana jest przede wszystkim czynnikami demograficznymi, czyli głównie gestościa zaludnienia. Oznacza to, że pomimo różnic $w$ poziomie rozwoju, produktywność ziemi jest relatywnie wysoka w Chinach $i$ UE, a niższa w USA. Wskazano też szereg dylematów rozwojowych, zwracajac uwage na społeczne znaczenie wieloaspektowego bezpieczeństwa zapewnianego przez rozwinięta gospodarkę, wskazując jednocześnie na zagrożenia środowiskowe.
\end{abstract}

Słowa kluczowe: rolnictwo światowe, oddziaływanie rolnictwa na środowisko, gazy cieplarniane, Stany Zjednoczone, Chiny, Unia Europejska.

Accepted for print: 19.04.2018.

Unless stated otherwise all the materials on the website are available under the Creative Commons Attribution 4.0 International license.

Some rights reserved to the Institute of Agricultural and Food Economics - National Research Institute.

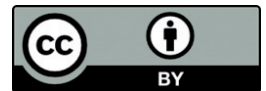

